\title{
校企合作模式下的研究生实践基地建设与管理一以新疆农业大 学农学硕士为例
}

\author{
王钰 李超
}

新疆农业大学

DOI:10.32629/er.v2i10.2096

[摘 要] 专业学位研究生教育离不开校外实践基地建设, 以校企合作为主体的产教融合模式能促进专业学位研究生培养, 有助于解决教育与产 业的失衡, 不断提高专业学位研究生培养水平。本文以新疆农业大学农业专业学位研究生培养为例,阐述了我校农业硕士实践基地建设情况和建 设过程中存在的问题与不足, 重点对研究生导师与企业开展横向课题合作, 促进校外实践基地建设与人才培养水平提供的作用进行了探讨, 为后 续进一步加强实践基地建设,提升专业学位研究生实践能力培养水平提供参考。

[关键词] 专业学位研究生; 实践基地; 研究生教育

随着研究生招生规模的逐年扩大, 硕士研究生就业去向已发生明显变 化, 越来越多的用人单位迫切需要大批高层次应用型人才, 对应用型人才 的创新能力、创业能力和实践能力提出了越来越高的要求, 而实践能力 的培养是造就高层次应用型人才的基础 ${ }^{[1-2]}$ 。开展全日制专业硕士实践 教学改革是提高研究生实践能力培养水平的重要措施 ${ }^{\left[{ }^{[3}\right.}$ 。全日制专业硕 士既要求提高科研实践能力, 又要提升理论联系实际, 突出解决实践问 题的能力 ${ }^{[4-5]}$ 。本文以新疆农业大学农业硕士校外实践基地建设, 以及双方 在合作研究、人才培养过程中的问题进行探讨, 以进一步拓展实践基地规 模, 深入开展合作研究, 进一步提升专业硕士实践能力培养水平, 为社会培 养高层次创新型和应用型人才提供支撑和保障。

\section{1 新疆农业大学农业硕士实践基地建设概况}

根据各专业学位研究生教指委要求和我校农业硕士人才培养方案的 规定, 为进一步探索产学结合培养专业学位研究生模式、落实好双导师制 度, 切实提高专业学位研究生的实践能力。为解决专业学位研究生人才培 养改革过程中, 实践教学基地贾乏, 综合利用效率不高的问题, 通过新建实 践教学基地, 从新建实践基地的要求, 建设形式, 实践基地的管理和评估等 方面进行研究。研究成果进一步增加了实践教学基地数量, 形成了一批以 九圣禾、中国农科院、新疆农科院、伊犁河谷、鲁泰集团以及青岛罗素为 代表的专业学位实践基地。完善了实践基地管理规章制度, 提升了校外实 践基地在人才培养过程中的作用, 让学生通过在实践基地的锻炼, 各项能 力得到了提升。同时进一步完善了学院与实践基地之间的协同育人机制, 整合统筹了学院现有的本科实习基地, 产学研基地以及专业硕士实践基地
资源, 更好的合理利用实践基地资源, 最大程度的发挥了实践教学, 协同育 人在专业学位研究生人才培养中的重要作用。

1. 1 创新导师合作模式

农学院在传统导师的基础上, 面对还不是我校批准导师的相关人员也 会根据实际情况分配一定数量的富余研究生参与到相关课题研究中, 使基 地老师和学生都得到了实惠。另外, 积极邀请对方的相关人员为研究生作 专题讲座和答辩评委, 形成了双方导师的良性互动。在人才培养的管理方 面, 新疆农业大学与实践基地本着 “平等、互利” 的原则, 由双方相关人员 组建的工作小组, 通过认真讨论, 明确分工, 签署基地建设的各项协议。通 过制定有关激励机制, 将基地指导教师和相关工作人员的报酬与教学效果 挂钩, 建立一批相对稳定的学、研、产教职工队伍。

1.2 以横向课题为驱动, 不断加强与实践基地合作

根据全日制专业硕士培养方案要求, 每一位专业硕士研究生, 需在专 业实践基地开展为期不少于 6 个月的实践训练。针对校外实践基地多以企 业为主的情况, 专业硕士研究生的实践训练内容需要紧扣企业生产需求, 结合校内外指导教师的共同研究领域, 开展农业生产中的实际问题研究。 因此, 为保证专业硕士研究生在实践训练中切实得到锻炼与提高, 需要不 断加强校企合作, 以横向课题为驱动, 让人才培养与合作研究不断深化。

2019年7月, 新疆农业大学和海南阿罗多甘农业科技有限公司启动了 横向课题 “海南省白沙县共享农庄昆虫资源调查与标本制作” 研究。该项 目以昆虫资源开发利用和农业害虫可持续控制为主要目标, 通过共享农庄 昆虫资源的系统调查以及标本采集鉴定与制作, 为白沙县旅游及农林业的

校思政教育教学实践进行创新。在进行职业院校思政教育教学实践设计时, 可以建立校园实践基地, 深入研究院校其他专业实训基地创建经验。想方 设法地讲社区服务对象、基地办事对象 “引进来、走出去” 进行深度融合， 唯有如此才能够更好地将学校生活和社会生活相结合, 杜绝理论和实际相 偏离的问题。

\section{3 总结}

现阶段, 我国职业院校在思想政治教育教学方面所取得的效果并不是 很理想。对此, 这就要以职业院校思政教育教学现状为立足点, 加深认知、 追求创新、强调提高, 全力推进职业院校思政教育教学的创新, 从而使学生 树立正确的三观, 也为国家、社会培育出合格的建设者与接班人。

[参考文献]

[1]周义芬.浅谈中等职业学校教案在思想政治教学中的教育作用 [J].

[2]刘云高.高职院校思想政治理论课教育教学创新研究 [J].湖北函授 大学学报,2016,29(23):44-45.

[3]林文树.新媒体视野下高职思想政治课正能量教育的路径探析[J]. 牡丹江教育学院学报,2018,(11):75-77.

[4]冯德安,孙志晧,刘晓旸.新时代高职院校思政课教育教学的创新与 发展——改革开放40周年高职院校思想政治理论课教育教学创新发展” 研讨会综述[J].北京教育(高教),2018,(09):36-38.

[5]陈荣. “工匠精神”融入高职思政教育的制约因素研究 [J].中国多 媒体与网络教学学报(中旬刊),2018,(11):97-98.

[6]刘学思.从 “思政课程” 到 “课程思政” ——高职院校思想政治理 论教育创新研究[J].经贸实践,2018,(20):296-297. 
可持续发展提供科学依据和较为详实的第一手资料。

该项目针对白沙县的共享农庄、茶园、果园等主要生境类型开展昆虫 资源调查, 获得白沙共享农庄主要昆虫名录, 主要危害情况及相关影像资 料; 根据主要昆虫种类和分布危害情况, 提出监测和防控对策与建议, 建立 阿罗多甘共享农庄昆虫知识库; 对采集的昆虫标本进行整理与鉴定, 建立 昆虫标本库。在白沙县内确定两条调查样线, 通过近一个月的野外调查与 采集, 共统计得到昆虫种类 80 余种, 其中害虫 40 余种, 检疫性入侵害虫名录 种类5种，已完成制作针插标本 2068 号，拍摄昆虫及危害状况照片500余张。

在阿罗多甘共享农庄内, 针对 10 余种, 重要害虫共设置了 50 余个诱捕 器, 1 张马来氏网进行害虫种群系统监测, 以期获得主要害虫种群消长动态 规律。根据野外调查结果, 获得阿罗多甘共享农庄昆虫基础数据, 同时提供 入侵害虫种群监测防控法规标准, 农业昆虫科普知识, 影像资料等相关信 息, 形成知识库。

\section{2 实践基地建设中存在的问题与思考}

2. 1专业硕士研究生培养方案需进一步优化

校外实践基地成立后, 双方负责人就现有的专业硕士学位研究生培养 方案进行了细致的探讨, 并结合校外基地现有研发条件和课题项目, 进一 步积极完善, 制订专业硕士学位研究生在实践基地期间的培养计划, 使专 业学位硕士研究生的实践能力培养与实践基地的研发需求更加契合。同时, 需结合专业硕士研究生在实践基地训练过程中, 存在的问题与不足, 进 一步修订完善相关培养计划, 包括在校期间的专业理论课程学习和专业 发展方向设置, 为专业硕士研究生今后在实践基地的实践训练创造更好 的条件。

2.2 校企双方在实践基地建设方面需加大资金投入, 惠及广大师生

当前, 我校专业硕士实践基地建设的投入尚显不足, 主要以研究生教 学改革项目支持实践基地的管理方案等理论研究方面, 而在实践基地运行 保障等方面, 多以实践基地的挂靠企业为主。对于实践基地运行保障的资 金投入, 不同企业的投入费用参差不齐, 缺乏具体标准, 例如, 在 2019 年我 院教师与海南共享农庄联合研发的横向课题中, 海南阿罗多甘农业科技有 限公司积极筹措资金, 建设了昆虫生态实验室, 提供了昆虫饲养, 观察所需 的人工智能气候箱, 数码互动体式显微镜等专用仪器设备, 极大地改善了 实践基地硬件水平。

目前, 一般以横向课题中的劳务费, 作为进入实践基地开展实验的专 业硕士研究生的生活补贴。作为学校或学院应加大实践基地的资金投入 如: 提高进入实践基地开展实践训练的研究生补助水平, 对负责专业硕士 研究生毕业论文指导的实践基地导师和校内导师给予一定补助等措施, 能 极大的提高导师参与专业硕士研究生实践教育的积极性, 不断推进了基地 建设和实践教学水平。

2. 3成果转化管理办法与深入合作有待加强

通过横向课题等形式开展的联合攻关形成的研究成果, 一般由实践基
地与学校共享, 实践基地可以作为试验示范单位对研发成果进行展示推广, 并享有优先使用成果的权利。但对于具体的成果转化管理办法细则, 尚需 要进一步深入研究, 以进一步提高研究生导师参与成果转化的积极性, 保 障各方在科技成果推广应用中的权利与义务。研究生导师积极通过学校以 技术支撑企业发展, 稳定校企合作, 实现实践基地的可持续发展。

为进一步探索产教融合培养专业学位研究生模式、落实好双导师制度, 切实提高专业学位研究生的实践能力, 需要不断加强专业学位研究生校外 教育实践基地建设工作。校外实践基地建设能够更好的提高研究生科研水 平和实践能力, 通过在一线的亲身经历和实践操作, 可以让学生迅速的成 长起来, 独立自主的思考能力和解决问题的能力得到提升。同时, 通过基地 提供的研发平台能够让学生开始思考 “实际生产需要什么”、“产业需要什 么” “科研该怎么做” 等一系列问题。后期应重点在对产学研结合政策环 境的构建上, 在今后的建设过程中, 希望逐渐摆脱对于校内和基地导师的 科研项目经费的依赖, 通过社会渠道的引导来加大对产学研结合各方面的 投入。丰富产学研交流方式。通过产学研交流平台, 鼓励和引导我院与基 地之间进行项目合作, 例如与基地联合申报科研项目, 从而使研究生与基 地的科研人员能够在一起进行更深层次的合作交流。

\section{[参考文献]}

[1]黄宝印.我国专业学位研究生教育发展的新时代[J].学位与研究生 教育,2010(10):25-27.

[2]汪全报, 卜春梅.专业学位研究生教育的产教融合——基于目标导 向的特色化策略 [J].学位与研究生教育,2019(3):24-29.

[3]张天天。研究生专业学位教育培养模式研究 [J].长春工程学院学报 (社会科学版),2018(3):43-46.

[4]赵宏伟,邹德堂,孙健.全日制作物专业硕士实践教学的改革与探索 - - 以东北农业大学作物专业学位研究生培养为例[J]. 教育教学论 坛,2019(9):113-115.

[5]杨映,李华,于辉.农业专业学位硕士研究生实践教育基地建设与探 索[J].教育现代化,2018(35):5-6.

\section{作者简介:}

王钰(1987--), 女, 汉族,武汉, 硕士, 新疆农业大学农学院, 研究生秘 书。主要从事研究生德育,培养管理方法与制度的理论思考与及实践 探索。

李超(1985--), 男,汉族,武汉,博士,副教授,新疆农业大学农学院。 主要从事害虫综合治理相关教学与科研工作。

\section{基金项目:}

新疆农业大学作物学重点学科创新基金项目; 横向课题一海南省 白沙县共享农庄昆虫资源调查与标本制作。 新疆农业大学2017年研究生教育教学改革研究项目。 